\title{
PENGARUH PELATIHAN DAN MOTIVASI KERJA TERHADAP KINERJA KARWAYAN DIVISI CORPORATE PADA PT TELKOM AKSES SINGARAJA
}

\author{
K. L. A. Lestari ${ }^{1}$, N. M. D. A. Mayasari² \\ 1, 2 Jurusan Manajemen, Universitas Pendidikan Ganesha, Singaraja, Indonesia \\ e-mail: liaayu265@gmail.com,dwi.mayasari@undiksha.ac.id
}

\begin{abstract}
Abstrak
Penelitian ini bertujuan menguji pengaruh: (1) pelatihan terhadap kinerja karyawan (2) motivasi kerja terhadap kinerja karyawan (3) pelatihan terhadap motivasi kerja (4) pelatihan dan motivasi kerja terhadap kinerja karyawan divisi corporate pada PT Telkom Akses Singaraja. Desain penelitian adalah kuantitatif kausal. Objek penelitian adalah pelatihan, motivasi kerja, dan kinerja karyawan. Subjek penelitian adalah seluruh karyawan divisi corporate yang terdiri dari divisi IOAN, divisi WIFI \& BGES yaitu sebanyak 34 orang. Data dikumpulkan dengan pencatatan dokumen, wawancara, observasi serta kuisioner dan dianalisis dengan analisis jalur. Hasil penelitian menunjukkan bahwa (1) pelatihan berpengaruh positif terhadap kinerja karyawan sebesar $33,5 \%$ (2) motivasi kerja berpengaruh positif terhadap kinerja karyawan sebesar $18,6 \%$ (3) pelatihan berpengaruh positif terhadap motivasi kerja sebesar $51,6 \%$ (4) pelatihan dan motivasi kerja berpengaruh terhadap kinerja karyawan sebesar $87,9 \%$ yang artinya secera keseluruhan adalah bahwa tinggi rendahnya kinerja karyawan dipengaruhi oleh pelatihan dan motivasi kerja.
\end{abstract}

Kata kunci: kinerja karyawan, pelatihan, motivasi kerja

\section{Abstract}

This study aims to look at the impact of: (1) coaching on worker performance (2) work motivation on employee performance (3) training on work motivation (4) training and work motivation on employee performance within the corporate division at atomic number 78 Telkom Akses Singaraja. The analysis style was causative quantitative. The research object is training, work motivation and employee performance. The research subjects were all staff of the company division consisting of the IOAN division, the wireless fidelity \& BGES division as several as thirty four people. information were collected by recording documents, interviews, observations and questionnaires and analyzed by path analysis. The results showed that (1) coaching had a positive effect on worker performance by $33.5 \%$ (2) work motivation had a positive effect on employee performance by $18.6 \%$ (3) training had a positive effect on work motivation by $51.6 \%$ (4) training and work motivation have a sway on employee performance by $87.9 \%$, which implies that overall, the amount of employee performance is influenced by training and work motivation.

Keywords : employee performance, training, work motivation

\section{Pendahuluan}

Perusahaan Telekomunikasi Indonesia (PT. TELKOM) merupakan sebuah perusahaan penyelenggaraan jaringan dan jasa telekomunikasi, informatika, serta optimalisasi pemanfaatan sumber daya yang dimiliki perseroan. Perusahaan ini berstatus terbuka dan bagian dari badan usaha milik negara (BUMN). PT Telkom terbagi atas beberapa anak perusahaan di berbagai wilayah provinsi maupun kabupaten.

Pada setiap wilayah perusahaan PT Telkom ini telah disebar secara merata ke dalam entitas anak perusahaan yang memiliki tugas dan fungsi yang berbeda, seperti PT Telkom Akses yang bergerak dalam jasa penggelaran dan pengelolaan infrastruktur jaringan akses fixed-broadband, dengan bisnis inti jasa konstruksi penggelaran jaringan akses fixedbroadband, managed service dan operation maintenance jaringan akses fixed-broadband. PT Telkom Akses Singaraja memiliki karyawan sebanyak 110 orang karyawan secara keseluruhan yang terbagi dalam berbagai divisi. Divisi corporate merupakan divisi dengan SDM terbanyak di Telkom Akses Singaraja, yaitu 34 karyawan. Pada divisi ini dibagi menjadi dua unit kerja, unit IOAN, unit WIFI \& BGES. 
Integrated Operation Access Network (IOAN) adalah unit kerja yang bertugas sebagai penanggung jawab dalam mengatasi gangguan indihome yang terjadi di rumah customer daerah Singaraja. Unit WIFI \& BGES bertugas dalam mengatasi setiap permasalahan mengenai pemasangan WIFI di sekolah dan universitas di Singaraja, mengatasi gangguan pada malam hari seperti kabel putus di jalan. Tugas ini membuat unit WIFI \& BGES untuk bekerja selama 24 jam. Disamping sekolah dan universitas unit kerja ini juga melayani pelayanan WIFI di beberapa kantor pemerintahan di Singaraja serta unit ini terfokus juga pada layanan bisnis bagi customer seperti Alfamart, Indomart, dan lain-lain. Hal ini mengaharuskan unit kerja ini untuk dapat menyelesaikan gangguan kurang dari 24 jam, mengingat keterlambatan penyelesaian gangguan akan mempengaruhi pelayanan pihak pemerintah dinas setempat kepada masyarakat. Hal ini dapat diartikan juga bahwa kinerja dari divisi corporate khususnya unit WIFI \& BGES rendah karena tidak dapat mengatasi permasalahan ataupun gangguan jaringan yang terjadi secara cepat dan akurat.

Kinerja karyawan khususnya pada bagian divisi corporate mengalami penurunan. Hal ini didasarkan pada data kinerja pada divisi corporate bagian unit IOAN diketahui bahwa selama 1 tahun yaitu tepatnya di tahun 2019 penurunan kinerja terjadi pada bulan Juli, September, Oktober dan Desember. Hal ini dapat dilihat dari persentase antara target dan pencapaian. Divisi Corporate tidak hanya mengenai unit IOAN saja, namun terdapat unit WIFI \& BGES yang memiliki standar kinerja dan hasil kerja karyawan selama 1 tahun. Berdasarkan data kinerja pada divisi corporate bagian unit WIFI \& BGES diketahui bahwa terdapat 5 parameter yang menjadi tugas dari unit WIFI \& BGES, namun dapat dilihat dari data diatas bahwa pada parameter Assurance Indihome dan Assurance EGBIS masih rendah. Hal ini dilihat dari bobot persentase yang dijadikan pengukuran dari unit ini dibandingkan dengan target pencapaiannya perparameter.

Diduga hal ini disebabkan kurangnya pelatihan dan motivasi kerja karyawan sehingga berpengaruh pada kinerja karyawan. Kinerja karyawan adalah hasil kerja yang dicapai sesuai dengan tanggung jawab yang dimiliki karyawan dalam bekerja untuk mencapai hasil yang optimal seperti tujuan dari perusahaan atau organisasi itu sendiri (Friska, 2018). Oleh karena itu, perlu adanya pelatihan sebagai bentuk upaya peningkatan keterampilan dan wawasan karyawan dalam bekerja. pelatihan merupakan sebuah bentuk upaya instansi atau organisasi dalam menambah wawasan, pengetahuan, dan keterampilan setiap pekerja yang nantinya akan berguna dalam meningkatkan kinerja karyawan sehingga lebih efektif (Faustino, 2003).

Pelatihan sebagai media pembelajaran dalam upaya peningkatan pemahaman dan cara kerja perdivisi atau perunit kerja di PT Telkom Akses Singaraja. Pelatihan yang diadakan dan disediakan serta difasilitasi oleh perusahaan haruslah berjalan seefektif mungkin dalam fungsi pelatihan tersebut sehingga mampu memberikan pemahaman bagi peserta yang mengikuti pelatihan. Selain itu pelatihan juga diharapkan dapat menjadi panduan ataupun petunjuk tata cara kerja yang baik dan benar sesuai yang diharapkan dari hasil diberikannya suatu pelatihan tersebut. Pelatihan yang efektif akan mampu meminimalisir terjadinya permasalahan ataupun hambatan-hambatan dalam bekerja yang diakibatkan ketidakpahaman karyawan mengenai tata cara melakukan pekerjaan yang semestinya.

Pada tahun 2019 telah dilakukan beberapa program pelatihan yang diikuti oleh karyawan dari PT Telkom Akses Singaraja. Jumlah program pelatihan yang dilaksanakan di tahun 2019 yaitu sebanyak 15 pelatihan dari pelatihan secara umum sampai pada mengkhusus. Pelatihan tersebut belum sepenuhnya efektif dalam pelaksaannya karena pelatihan yang telah dilaksanakan jumlahnya tidak sama dan tidak konsisten setiap tahunnya. Pelatihan yang diadakan hanya berdasarkan keputusan manajemen yaitu pihak manajer sebagai pimpinan, hal ini membuat beberapa kebutuhan pelatihan yang sesungguhnya dibutuhkan oleh karyawan, utamanya karyawan junior terabaikan.

Program pelatihan tidak diikuti oleh seluruh karyawan PT Telkom Akses Singaraja akan tetapi diwakilkan oleh beberapa karyawan saja dimana karyawan yang dikirim sebagai delegasi adalah orang yang sama. Hal ini menunjukkan kurang adanya pemerataan kesempatan dan hak terhadap karyawan lainnya. Selain itu dari hasil observasi dan 
wawancara, dalam bidang pelatihan masalah yang seringkali terjadi yaitu pelatihan yang diberikan tidak dilakukan secara intensif bahkan dalam setahun jumlah program pelatihan yang diberikan tidak menentu. Jenis pelatihan yang diberikan seringkali tidak sesuai dengan apa yang dibutuhkan oleh karyawan atau dimana sejatinya pelatihan merupakan hal terpenting bagi seluruh karyawan.

PT Telkom Akses Singaraja bergerak pada bidang jaringan yang notabene memiliki sistem yang sangat sensitif terhadap fenomena alam dan lain sebagainya yang nantinya dapat menyebabkan terjadinya gangguan jaringan dalam satu wilayah yaitu Singaraja. Pelatihan yang sangat dibutuhkan sebenarnya oleh karyawan PT Telkom Akses Singaraja yaitu pelatihan di bidang penggunaan pelaratan dan prasarana yang telah disediakan oleh perusahaan dengan tujuan untuk meningkatkan keterampilan, pengetahuan, dan cara menjaga serta menggunakan peralatan tersebut agar dapat meminimalisir kerusakan yang terjadi yang nantinya berdampak pada kerugian biaya penyusutan yang lebih besar terhadap peralatan yang disalah pergunakan oleh karyawan akibat faktor kurangnya pengetahuan dan arahan yang tidak disampaikan oleh atasan dan tidak diberikannya pelatihan terkait hal tersebut.

Materi pelatihan dan metode pelatihan yang digunakan seringkali tidak selaras sehingga karyawan sebagai peserta sulit untuk memahami dan mengimplementasikan pelatihan yang telah diikuti dalam proses pelaksanaan pekerjaan atau tanggung jawabnya dalam bekerja. Hal ini dapat berimbas pada motivasi kerja setiap karyawan karena motivasi kerja ialah dorongan yang muncul dari dalam diri (Ardana,dkk, 2012). Dengan pelatihan yang baik dan sesuai kebutuhan maka dapat meningkatkan motivasi kerja atau semangat kerja karena karyawan merasa aman dan nyaman dalam bekerja sebab sudah menguasai bidang yang akan dikerjakan melalui pelatihan yang sudah diikuti sebelumnya.

Penurunan motivasi kerja karyawan pada PT Telkom Akses Singaraja disebabkan oleh ketidak jelasan dalam pengarahan, pembagian tugas dan pekerjaan yang menumpuk. Miss communication juga seringkali terjadi pada saat sedang banyak pekerjaan, hal ini menyebabkan kesalahpahaman yang berakibat terabaikannya beberapa pekerjaan yang seharusnya dapat diselesaikan pada hari itu juga. Keadaan yang seperti ini membuat karyawan merasa berada pada lingkungan yang tidak menyenangkan sehingga dapat menurunkan motivasinya dalam bekerja. Melalui pemberian pelatihan maka diharapkan dapat membantu karyawan untuk meningkatkan motivasi sehingga kinerja akan meningkat, ini juga dapat dilihat pada hasil kerja dari karyawan itu sendiri setelah diberikannya pelatihan oleh pihak perusahaan atapun dilihat dari prestasi kerja yang dicapai pada satu periode yang dapat dijadikan tolok ukur pihak manajemen ataupun pihak PT Telkom Akses Singaraja untuk menentukan implikasi atau hasil dari pelatihan.

Berdasarkan permasalahan di PT Telkom Akses Singaraja telah terjadi kesenjangan antara keadaan di perusahaan dengan teori yang ada. Hasil penelitian dari Susanti (2018) menyatakan pelatihan dan motivasi kerja berdampak positif terhadap kinerja karyawan yang berarti apabila pelatihan yang dilakukan efektif maka motivasi dan kinerja karyawan akan meningkat. Sejalan dengan penelitian Agusta (2013) mengungkapkan pelatihan serta motivasi kerja berpengaruh positif dan signifikan terhadap kinerja karyawan. Hasil penelitian dari Samuel, dkk (2018) juga menyatakan pelatihan dan motivasi kerja berpengaruh signifikan terhadap kinerja karyawan, akan tetapi Pramana (2019) menyatakan motivasi kerja tidak berpengaruh signifikan terhadap kinerja karyawan, sedangkan pelatihan berpengaruh signifikan terhadap kinerja karyawan. Latar belakang permasalahan diatas menunjukkan adanya perbedaan hasil penelitian sebelumnya dengan yang terjadi pada PT Telkom Akses Singarja.

Berdasarkan pemaparan diatas, disimpulkan kinerja karyawan di pengaruhi oleh pelatihan dan motivasi kerja. Oleh karena itu peneliti tertarik melakukan penelitian ini dengan judul "Pengaruh Pelatihan dan Motivasi Kerja Terhadap Kinerja Karyawan Divisi Corporate Pada PT Telkom Akses Singaraja." 


\section{Metode}

Penelitian ini adalah penelitian kuantitatif dengan desain penelitian kausal. Variabel dalam penelitian yaitu variabel bebas dan variabel terikat. Variabel bebas pada penelitian ini adalah pelatihan $\left(X_{1}\right)$ dan motivasi kerja $\left(X_{2}\right)$, sedangkan untuk variabel terikat adalah kinerja karyawan $(Y)$. Subjek dalam penelitian ini adalah karyawan divisi corporate yang terdiri dari divisi IOAN, divisi WIFI \& BGES, dengan objek penelitian yaitu pelatihan, motivasi kerja, dan kinerja karyawan. Jumlah populasi sebanyak 34 orang, karena seluruh populasi merupakan subjek penelitian maka penelitian ini disebut penelitian populasi.

Metode pengumpulan data dilaksanakan dengan pencatatan dokumen, wawancara, observasi serta kuisioner. Sumber data dalam penelitian ini adalah data primer yang didapat secara langsung oleh peneliti dari pemimpin atau pegawai yang berwenang memberikan informasi. Sumber data ini berasal dari pegawai dan pimpinan pada Divisi Corporate pada PT Telkom Akses Singaraja melalui kuesioner yang berupa data mengenai pelatihan, motivasi kerja, dan kinerja karyawan. Data sekunder adalah sata yang telah tersedia pada tempat penelitian.Data sekunder pada penelitian ini adalah data program pelatihan yang dilaksanakan dan data karyawan dari divisi corporate.

Kuesioner penelitan harus memenuhi syarat validitas dan reliabilitas. Kuesioner dikatakan valid (sah) jika pertanyaan pada kuesioner mampu mengungkapkan hal yang akan diukur. Kriteria pengujian yaitu: (1) valid apabila $p$-value $<0,05$, (2) tidak valid apabila $p$ value>alpha 0,05. Sedangkan kuesioner dikatakan reliabel (andal) apabila jawaban responden konsisten atau stabil dari waktu ke waktu. Kriteria pengujian apabila reliabilitas $\left(r_{i}\right)$ $>0,60$. Pengolahan data dilaksanakan dengan program Statistical Package For Social Science (SPSS) 20.0 for Windows.

Tujuan penelitian ini adalah menganalisis pengaruh pelatihan dan motivasi kerja terhadap kinerja karyawan PT Telkom Akses Singaraja secara parsial maupun simultan dengan metode analisis jalur (path analysis). Sarwono (2007) menyatakan analisis jalur merupakan teknik untuk mengetahui hubungan sebab akibat pada regresi berganda secara langsung atau tidak langsung.

\section{Hasil dan Pembahasan}

Struktur hubungan pada penelitian ini nampak pada Gambar 4.1.

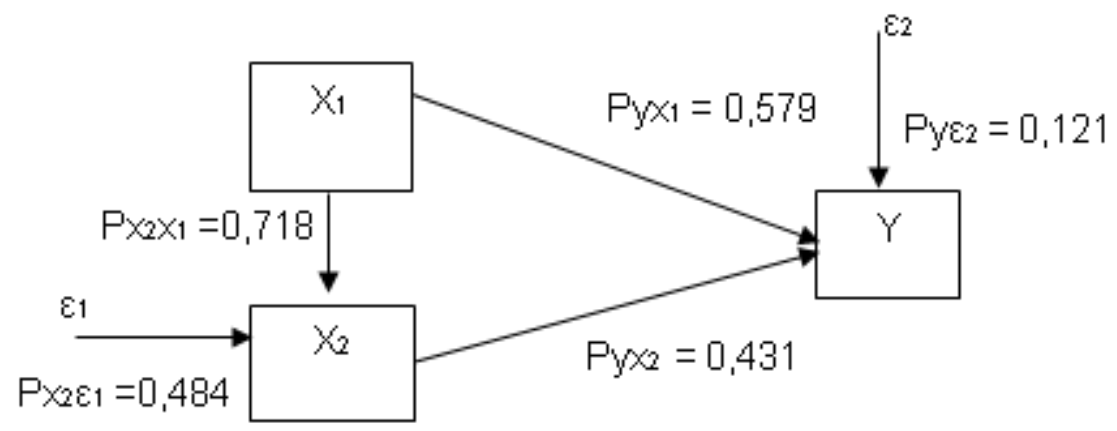

\section{Gambar 1. Struktur Hubungan Pengaruh Pelatihan dan Motivasi Kerja Terhadap Kinerja Karyawan}

Hasil uji analisis jalur diperoleh $\mathrm{Pyx}_{1}=0,579$ dengan $p$-value $=0,000<0,05$ sehingga keputusannya adalah $\mathrm{H}_{0}$ ditolak, dimana ada pengaruh pelatihan $\left(\mathrm{X}_{1}\right)$ terhadap kinerja karyawan $(\mathrm{Y})$ pada Divisi Corporate PT Telkom Akses Singaraja dengan besar sumbangan pengaruh adalah 0,335 atau $33,5 \%$.

Hasil $\mathrm{Pyx}_{2}=0,431$ dengan $p$-value $=0,000<0,05$ sehingga keputusannya adalah $\mathrm{H}_{0}$ ditolak, dimana ada pengaruh motivasi kerja $\left(\mathrm{X}_{2}\right)$ terhadap kinerja karyawan ( $\mathrm{Y}$ ) Divisi Corporate pada PT Telkom Akses Singaraja dengan besar sumbangan pengaruh adalah 0,186 atau 18,6\%. Hasil $\mathrm{Px}_{2} \mathrm{X}_{1}=0,718$ dengan $p$-value $=0,000<0,05$ sehingga keputusannya adalah $\mathrm{H}_{0}$ ditolak, dimana ada pengaruh pelatihan $\left(\mathrm{X}_{1}\right)$ terhadap motivasi kerja 
$\left(\mathrm{X}_{2}\right)$ Divisi Corporate pada PT Telkom Akses Singaraja dengan besar sumbangan pengaruh adalah 0,516 atau 51,6\%. Hasil $\operatorname{Ryx}_{1} \mathrm{x}_{2}=0,938$ dengan $p$-value $=0,000<0,05$ sehingga keputusannya adalah $\mathrm{H}_{0}$ ditolak, dimana ada pengaruh pelatihan $\left(\mathrm{X}_{1}\right)$ dan motivasi kerja $\left(\mathrm{X}_{2}\right)$ berpengaruh terhadap kinerja karyawan $(\mathrm{Y})$ Divisi Corporate pada PT Telkom Akses Singaraja dengan besar sumbangan pengaruh adalah 0,879 atau $87,9 \%$.

Penelitian ini memperoleh hasil variabel pelatihan berpengaruh positif terhadap kinerja karyawan Divisi Corporate pada PT Telkom Akses Singaraja dengan $p$-value $\mathrm{Pyx}_{1}=$ $0,000<0,05$. Hasil ini sejalan dengan teori Raymond (2010) bahwa upaya peningkatan kinerja karyawan dapat dilakukan melalui pemberian pelatihan oleh perusahaan. Senada dengan itu, Hubeis (2007) menyatakan kinerja karyawan dipengaruhi oleh faktor ektrinsik, salah satunya adalah pelatihan.

Menurut Kusriyanto (2003) pelatihan memiliki dampak langsung meningkatkan keterampilan serta pengalaman kerja. Senada dengan itu, Hasibuan (2006) mengungkapkan pelatihan dapat meningkatkan dan membentuk pengetahuan serta ketrampilan karyawan sehingga apabila interval pelaksaan pelatihan semakin tinggi maka tingkat kinerjanya akan semakin tinggi juga. Mangkunegara (2013) mengungkapkan tujuan pelatihan yaitu mengembangkan keahlian, pengetahuan dan sikap untuk menyelesaikan pekerjaansecara efektif dengan kerjasama antara pegawai dan manajemen (pimpinan). Dapat disimpulkan bahwa pelatihan berdampak pada kinerja karyawan. Peningkatan kinerja karyawan merupakan prioritas perusahaan yang dapat dilakukan dengan mengembangkan kualitas tenaga kerja melalui pelatihan yang berkesinambungan.

Terkait dengan hal tersebut, realita pelatihan di lapangan yang terjadi pada karyawan Divisi Corporate pada PT Telkom Akses Singaraja menunjukkan bahwa kondisi indikator tujuan pelatihan mendapatkan penilaian terendah dari responden. Artinya, karyawan Divisi Corporate pada PT Telkom Akses Singaraja merespon bahwa pelatihan yang diberikan belum dilakukan secara intens untuk menambah keterampilan karyawan dalam bekerja. Dengan demikian, PT Telkom Akses Singaraja harus memperhatikan pelatihan yang bertujuan untuk menambah keterampilan karyawan dalam menyelesaikan pekerjaannya.

Hasil ini diperkuat oleh penelitian dari Sugiarti (2016) yang menyatakan bahwa pelatihan berdampak signifikan meningkatkan kinerja karyawan. Budiartha, dkk (2015) juga mengungkapkan pelatihan meningkatkan produktivitas kerja karyawan secara signifikan. Senada dengan hasil penelitian Oktaviani (2017) pelatihan secara parsial berpengaruh terhadap kinerja pegawai. Penelitian oleh Bismantara (2017) menguatkan hasil penelitian ini, dimana secara parsial pelatihan berpengaruh pada kinerja. Senada dengan hasil penelitian oleh Susanti (2018) pelatihan memiliki pengaruh baik terhadap kinerja karyawan. Hasil penelitian Pramana (2019) juga menunjukkan bahwa pelatihan berpengaruh pada kinerja secara parsial. Oleh sebab itu maka disimpulkan pelatihan berpengaruh terhadap kinerja karyawan.

Pada variabel motivasi kerja berpengaruh positif terhadap kinerja karyawan, hal ini ditunjukan dengan $p$-value $\mathrm{Pyx}_{2}=0,000<0,05$. Hasil sesuai dengan teori dari Wibowo (2012) yang menyatakan bahwa motivasi kerja merupakan faktor yang mempengaruhi kinerja karyawan. Peningkatan motivasi kerja akan akan sejalan dengan peningkatan kinerja individu maupun kelompok. Hal ini sejalan dengan hasil penelitian oleh Sembiring (2019) yang mengungkapkan peningkatan kinerja dipengaruhi oleh motivasi dan lingkungan kerja yang baik.

Terkait dengan hal tersebut, realita motivasi di lapangan yang terjadi pada karyawan Divisi Corporate pada PT Telkom Akses Singaraja menunjukkan bahwa kondisi indikator lingkungan kerja yang menyenangkan mendapatkan penilaian terendah dari responden. Artinya, karyawan Divisi Corporate pada PT Telkom Akses Singaraja merespon bahwa lingkungan kerja yang selama ini dirasakan kurang begitu nyaman. Hal ini dapat menyebabkan terjadinya penurunan motivasi dalam bekerja. Dengan demikian, PT Telkom Akses Singaraja harus memberikan perhatian pada motivasi kerja dengan cara melakukan pembagian tugas dan arahan yang jelas dan menghindari penumpukan pekerjaan. Komunikasi yang baik sangat perlu dilakukan agar tidak terjadi miss communication pada saat karyawan sedang banyak pekerjaan, sehingga tidak menyebabkan kesalahpahaman. 
Keadaan yang seperti ini membuat karyawan merasa berada pada lingkungan yang menyenangkan sehingga dapat mengingkatkan motivasi kerja.

Hasil penelitian ini diperkuat oleh Rachmawati (2016) yang menyatakan bahwa motivasi kerja yang tinggi maka kinerja karyawan akan meningkat begitupula sebaliknya. Senada dengan Heruwanto, ddk. (2018) yang menyatakan bahwa motivasi kerja memiliki pengaruh yang positif dan siginifikan terhadap kinerja karyawan. Hal ini juga sejalan dengan Budiartha, dkk (2015) yang menemukan bahwa variabel motivasi kerja berpengaruh positif dan signifikan terhadap produktivitas kerja karyawan. Hasil penelitian Susanti (2018) menunjukkan motivasi kerja berpengaruh positif terhadap kinerja karyawan. Dengan demikian, dapat disimpulkan bahwa motivasi kerja berpengaruh terhadap kinerja karyawan.

Penelitian mengenai pengaruh dari variabel pelatihan terhadap motivasi kerja menunjukkan bahwa pelatihan secara positif berpengaruh terhadap motivasi kerja Divisi Corporate pada PT Telkom Akses Singaraja. Hal tersebut ditunjukan dengan $p$-value $\mathrm{Px}_{1} \mathrm{x}_{2}$ $=0,000<0,05$. Hasil penelitian ini sesuai dengan teori yang dikemukakan oleh Simamora (2015) bahwa pelatihan dan pengembangan adalah cara untuk memotivasi dan meningkatkan keterampilan kerja, termasuk pemberian konseling pada perilaku karyawan dan menindak lanjuti dengan pengadaan training. Menurut Rivai (2011), peningkatan motivasi kerja dapat ditingkatkan dengan pelatihan yang memadai. Senada dengan itu, Wibowo (2012) mengemukakan interval pelatihan yang tinggi akan meningkatkan motivasi dan kinerja karyawan. Menurut Sedarmayanti (2013) pelatihan dapat meingkatkan ketidaktahuan karyawan karena kepercayaan diri, pendidikan dan pengalaman yang kurang.

Hasil penelitian ini diperkuat oleh hasil Darmawan, dkk. (2017) yang menemukan bahwa peningkatan motivasi kerja dipengaruhi oleh pelatihan. Hal ini sejalan dengan Riani, dkk. (2017) yang menyatakan pelatihan memiliki pengaruh penting dengan motivasi karyawan. Senada dengan itu, Witono (2018) juga menyatakan pelatihan berpengaruh terhadap motivasi kerja karyawan. Dengan demikian, dapat disimpulkan bahwa pelatihan berpengaruh terhadap motivasi karyawan.

Berdasarkan penelitian yang telah dilakukan, maka diperoleh temuan bahwa variabel pelatihan dan motivasi kerja berpengaruh signifikan terhadap kinerja karyawan Divisi Corporate pada PT Telkom Akses Singaraja. Hal tersebut ditunjukan dengan $p$-value $\operatorname{Ryx}_{1} x_{2}=0,000<0,05$. Hasil penelitian ini sesuai dengan teori yang dikemukakan oleh Raymond (2010) bahwa upaya memecahkan masalah terkait dengan peningkatan kinerja karyawan dapat dilakukan melalui pemberian motivasi kerja dan pelatihan oleh perusahaan kepada karyawannya sehingga dapat meningkatkan kinerja dari karyawan itu sendiri. Menurut Wibowo (2012) interval pelatihan yang tinggi akan sejalan dengan motivasi kerja. Sejalan dengan penelitian Rumyati (2010) menyatakan pelatihan yang baik akan linier dengan motivasi kerja yang meningkat .

Hasil ini diperkuat oleh penelitian Budiartha, dkk (2015) yang menunjukan produktivitas kerja karyawan dipengaruhi oleh pelatihan dan motivasi kerja. Sejalan dengan hal tersebut, Oktaviani (2017) menyatakan secara simultan variabel pelatihan dan motivasi kerja berpengaruh positif dan signifikan terhadap kinerja pegawai. Penelitian yang dilakukan oleh Bismantara (2017) menguatkan hasil penelitian ini, dimana secara simultan motivasi kerja dan pelatihan berpengaruh signifikan terhadap kinerja karyawan. Senada dengan itu, hasil penelitian yang dilakukan oleh Susanti (2018) menunjukkan bahwa pelatihan dan motivasi kerja memiliki pengaruh positif terhadap kinerja karyawan. Hasil penelitian yang dilakukan oleh oleh Pramana (2019) juga menunjukkan bahwa pelatihan dan motivasi kerja berpengaruh terhadap kinerja karyawan secara simultan.

\section{Simpulan dan Saran}

Berdasarkan hasil dan pembahasan yang telah dilakukan, dapat disimpulkan bahwa pertama, pelatihan berpengaruh terhadap kinerja karyawan secara positif. Kedua, motivasi kerja berpengaruh terhadap kinerja karyawan secara positif. Ketiga, pelatihan berpengaruh positif terhadap motivasi kerja. Keempat, pelatihan dan motivasi kerja berpengaruh positif terhadap kinerja karyawan. 
Adapun beberapa saran untuk kedepannya yaitu pertama, peningkatan kinerja pada perusahaan dapat dilakukan dengan pelatihan dan motivasi kerja, karena terbukti dapat meningkatkan kinerja karyawanBeberapa hal yang dapat diperhatikan dalam pelatihan yaitu: (1) Memberikan pelatihan secara efektif dan rutin apabila diperlukan lakukan penjadwalan dalam hal pemberian pelatihan. (2) Memberikan pelatihan secara merata kepada seluruh karyawan sesuai bidang pekerjaannya agar lebih menguasai bidang pekerjaan yang dibebankan. Faktor motivasi kerja juga perlu mendapat perhatian dengan cara:(1) memperhatikan pembagian tugas dan pekerjaan yang jelas agar tidak terjadi miss comunication antar karyawan. (2) memberikan arahan kerja dan kejelasan waktu penyelesaian pekerjaan yang jelas kepada karyawan sehingga karyawan dapat meniingkatkan lagi semangat kerjanya dan tentunya untuk menghindari kesalahan yang terjadi yang disebabkan oleh arahan yang kurang jelas. Bagi peneliti lain yang tertarik untuk mengembangkan penelitian ini bisa menggunakan subjek yang lebih luas dan dapat menguji variabel seperti kompetensi, kepemimpinan, lingkungan kerja, kepuasan kerja, stres kerja, dan komitmen individu.

\section{Daftar Pustaka}

Agusta, Leonando, dan Eddy Madiono Sutanto. 2013. "Pengaruh Pelatihan Dan Motivasi Kerja Terhadap Kinerja Karyawan CV Haragon Surabaya". Jurnal AGORA, Vol. 1, No. 3, ISSN: $1121-1331$.

Ardana, I Komang, dkk. 2012. Manajemen Sumber Daya Manusia. Yogyakarta: Graha Ilmu.

Bismmantara. 2017. "Pengaruh Pemberian Motivasi Dan Pelatihan Kerja Terhadap Kinerja Karyawan". Jurnal Kewirausahaan, Vol. 3, No 2, ISSN: $2301-6264$.

Budiartha, Novrada, dkk. 2015. "Pengaruh Pelatihan Dan Motivasi Kerja Terhadap Produktivitas Kerja Karyawan". Jurnal Manajemen, Vol.3. Singaraja: e-Journal Bisma Universitas Pendidikan Ganesha.

Darmawan, Yuyun Yuniar, Wayan Gede Supartha, dan Agoes Ganesha Rahyuda. 2017. EJurnal Ekonomi dan Bisnis Universitas Udayana, Vol. 6, No. 3.

Faustino, Cardono Gomes. 2003. Manajemen Sumber Daya Manusia. Yogyakarta: CV. Andi Offset.

Friska, Susanti. 2018. "Pengaruh Pelatihan Dan Motivasi Kerja Terhadap Kinerja Karyawan Pada Perusahaan Manufaktur di Batam". Journal Of Applied Managerial Accounting, Vol.2, No. 1, ISSN: $2548-9917$.

Hasibuan, Malayu S. P. 2006. Manajemen Dasar, Pengertian, dan Masalah. Jakarta: Bumi Aksara.

Heruwanto Joni, Dede Septian dan Ergo Nurpatria Kurniawan. 2018. Pengaruh Motivasi dan Lingkungan Kerja Terhadap Kinerja Karyawan PT. Putra Taro Paloma Bogor. Jurnal Manajemen Kewirausahaan, Vol. 15, No. 2.

Hubeis. 2007. Manajemen Mutu Sumber Daya Manusia. Bogor: Penerbit Ghalia Indonesia.

Kusriyanto, Garda. 2003. Riset Sumber Daya Manusia. Jakarta: PT. Gramedia Pustaka Utama.

Mangkunegara, Anwar Pabu. 2013. Manajemen Sumber Daya Manusia. Bandung: Perusahaan Rosta.

Oktaviani, Evi, dan Ika Suhartanti Darmo. 2017. "Pengaruh Pelatihan Dan Motivasi Kerja Terhadap Kinerja Pegawai Sekretariat Direktorat Jendral Pengelola Pembiayaan Dan Risiko Kementrian Keuangan". Jurnal Riset Manajemen dan Bisnis (JRMB), Vol. 2, No 3, ISSN: $2581-2165$. 
Pramana, Dodi. 2019. "Pengaruh Pelatihan Dan Motivasi Kerja Terhadap Kinerja Karyawan Pada PT. Petrokimia Cabang Medan". Journal For Business And Entrepreneur, Vol. 3, No 29-35, ISSN: $2501-6682$.

Rachmawati, Fransisca. 2016. Pengaruh Pelatihan Kerja dan Motivasi Kerja terhadap Kinerja Karyawan pada PT Trias Sentosa, Krian Sidoarjo. Agora, Vol. 4, No. 2.

Raymond, A., dan John Neo, dkk. 2008. Human Resources Management: Gaining A Competitive Advantage, $6^{\text {th }}$ Edition, McGraw-Hill/Irwin.

Riani, Maulia Eka, M. Syamsul Maarif, dan Joko Affandi. 2017. PengaruhProgram Pelatihan Dan Motivasi Kerja Terhadap Kinerja Karyawan PT. TD Automotive Compressor Indonesia. Jurnal Aplikasi Bisnis dan Manajemen, Vol. 3, No. 2.

Rivai, Verhzal. 2011. Manajemen Sumber Daya Manusia untuk Perusahaan. Edisi Kedua. Jakarta: PT. Raya Grafindo Persada.

Rumyati, Sri. 2010. Pengaruh Pelatihan Terhadap Motivasi Kerja Karyawan Baru PT ANTAM Tbk Kantor Pusat. Skripsi (tidak diterbitkan). Jakarta: Fakultas Ekonomi Universitas Mercu Buana.

Samuel, Abraham Kaengke, dkk. 2018. "Pelatihan Pengembangan Karir, Pelatihan, Dan Motivasi Terhadap Kinerja Karyawann Pada PT. Air Manado". Jurnal EMBA, Vol. 6, No 1. ISSN: $2303-1174$.

Sarwono, Jonathan. 2007. Analisis Jaluruntuk Riset Bisnis dengan SPPS. Yogyakarta: Andi.

Sedarmayanti. 2013. Manajemen Sumber Daya Manusia. Bandung : PT Refika Aditama.

Sembiring, H. 2019. "Pengaruh Motivasi dan Lingkungan Kerja terhadap Kinerja Karyawan pada Bank Sinarmas Medan". Jurakunman, Vol. 1, No. 11, 26-39.

Simamora, Henry. 2015. Manajemen Sumber Daya Manusia. STIE YPKN: Yogyakarta.

Sugiarti. 2016. Pengaruh Pelatihan Kerja Terhadap Kinerja Karyawan Pada PT Padma Ardya Aktuaria Jakarta. Epigram, Vol. 13, No. 1.

Sugiyono. 2009. Metode Penelitian Pendidikan Pendekatan Kuantitatif, Kualitatif, dan R\&D. Bandung: Alfabeta

Susanti, Friska Butar Butar, dan Irsutami. 2018. "Pengaruh Pelatihan Dan Motivasi Kerja Terhadap Kinerja Karyawan". Journal Of Applied Managerial Accounting, Vol. 2, No.1, ISSN: 2548 - 9917.

Wibowo. 2012. Manajemen Kinerja. Jakarta: PT. Raja Grafindo Persada.

Witono, Maria Goretti Ruth Fania Retnaning. 2018. Pengaruh Pelatihan Terhadap Motivasi Kerja Karyawan Studi pada Karyawan Tetap PT. Dua Kelinci. Skripsi. Program Studi Manajemen Jurusan Manajemen, Fakultas Ekonomi, Universitas Sanata Dharma, Yogyakarta. 